\title{
A Business Survival Framework for African Immigrant-Owned Businesses in the Cape Town Metropolitan Area of South Africa
}

\author{
Dr. Robertson K. Tengeh \\ Faculty of Informatics and Design, \\ Cape Peninsula University of Technology. \\ Email:rtengeh@yahoo.com.
}

\author{
Doi:10.5901/mjss.2013.v4n13p247
}

\begin{abstract}
Using incoming revenues and the associated costs that underpin the concept of breakeven analysis, this article investigates the business survival strategies of immigrant-own-businesses in the context of African immigrants in the Cape Town Metropolitan Area of South Africa, and proposes a framework for the start-up survival of these businesses. The study was designed within the quantitative and qualitative research paradigms. A triangulation of three methods was utilised to collect and analyze the data. The research revealed that African immigrant entrepreneurs face a range of challenges when starting their businesses and again as they try to grow or stay afloat. Furthermore, the study indicated that African immigrants rely more on certain entrepreneurial attributes as they seek innovative solutions to the problems that they encounter relating to business. As a business survival strategy, these immigrants develop a number of unconventional initiatives aimed at increasing sales revenue while minimising cost.
\end{abstract}

Keywords: immigrant-owned businesses, business survival framework, African immigrants, entrepreneurial characteristics and business obstacles.

\section{Introduction}

The literature on small business and economic development includes the issue of promoting small business start-up and reducing the small business failure rate which are two parallel challenges faced by practitioners and scholars of entrepreneurship and economic development. On the one hand, as pro- SMME lobbyist (Sinha, 2003; Lee, Florida \& Acs, 2004; Markova \& Petkovska-Mircevska, 2009) promote a huge small business sector, on the other hand, those against a huge SMME sector are weary of the high failure rate associated with small businesses (Acs, 2001:41; Chandra, Moorty, Nganou, Rajaratnam, \& Schaefer, 2001). Amidst, this excitement and worry, not only has a high business startup rate has been associated with the immigrant community, a significant failure rate has also been noted too (OECD, 2010).

Starting and running a business is not 'an end in itself' but rather a 'means to an end'. Here, the end may vary depending on the motivation. People are either 'pushed; or 'pulled' into self-employment (Guzy, 2006; Pinkowski, 2009; Tengeh, Ballard \& Slabbert, 2011). However, Aldrich and Waldinger (1990) point out that founding and running a business, no matter how small, is a demanding task and only a fraction of those who start are ultimately successful.

Regardless of the reason or mode of entry, all business owners strive to succeed. In order to ensure continuity, referred to as success, the business has to be profitable or self-sufficient (Kloosterman \& Rath, 2001) and this can only be achieved if the business is run in a particular manner. Understanding the process that ensures the success of a business becomes important in achieving the overall goal of the business. In the quest to understand how to make a success of a business, land, labour, capital and entrepreneurship have been found to be vital factors (Federal Reserve Bank of Dallas, 2010). A growing concern, however, is the inherent difference in the endowment of these factors across regions and within the same geographical space: how well these factors are combined determines the success of a business.

In addition to the traditional factors of production associated with starting and operating a business, Tesfom (2006) notes the importance of other loosely related factors such as the business environment, having the entrepreneurial drive, the necessary skills, the regulatory environment, and finance among other things. Certain resources are infinite whilst others are limited. Once the business is started, its survival and growth depends on the aforementioned factors.

Given the perceived importance of business-related resources for business start-up and operation (Cassia, 2006) 
and the apparent lack thereof in South Africa (especially with regard to finances from formal financial institutions for immigrants), coupled with the growing need for more businesses to be started, it becomes obvious that every avenue should be explored to ensure the survival of newly started businesses. In the absence of enough employment opportunities, further compounded by the nature of the work permits (mostly short-term and inconsistent) issued to most immigrants and particular the immigrants under study, the most logical first step in pursuing an economic activity in their host country becomes starting a small business.

According to Rogerson (2000), a key issue for policy development surrounding SMMEs concerns the determinants of successful SMMEs. In South Africa, Rogerson (2000) further notes that the current 'state of the art' of research is relatively low with regards to work on the determinants of success in the small enterprise economy. A close look at the immigrant community and at immigrant businesses, certain similarities as well as inter-group differences in the way they start up and operate their businesses in South Africa may be identified. However, little is known about the strategies utilised to make a success of a business. Given the afore, it becomes important to understand how these immigrantowned businesses operate, given that they have limited or no access to formal business-related support institutions.

Considering the increasing number of immigrants in South Africa today and the high level of unemployment, an extensive debate, analysis and attention would be expected on how immigrants can contribute meaningfully to the economy through self-employment. Such a debate may relate to immigrant self-employment patterns and businesses. On the contrary, the literature on immigrant-owned businesses in South Africa has been largely overlooked and neglected by academics and researchers. Rarely have immigrant-owned businesses been singled out and treated in their own right. A discouraging aspect given the fact that studies conducted on immigrant-owned businesses elsewhere all attest to the huge potential of immigrant entrepreneurs, and the positive contribution that they can make with regards to reducing unemployment.

Although the immigrant community is generally associated with having a higher tendency towards entrepreneurship with a subsequent higher business start up rate than the natives (Van Tubergen, 2005; Pinkowski, 2009), they are, nonetheless, also prone to failure within the first three years following start-up. Limited job opportunities force African immigrants into self-employment (Tengeh, et al, 2011). However, due to numerous start-up and operation challenges, only a few of these immigrant-owned businesses survive beyond three years or grow. In this article, it is argued that most of these African immigrant-owned businesses fail to reach their full potential, because the owners are unable to develop efficient survival strategies.

The question this article seeks to address is: what survival strategies do African immigrants employ in an effort to prolong the survival of their business. Arguing that the survival strategies devised by African immigrants are in response to the challenges they face as well as the salient entrepreneurial characteristics they possess, the following sub questions are formulated:

- What problems do African immigrants encounter as they start-up and operate a business in South Africa?

- What entrepreneurial characteristic(s) do African immigrants perceive as effective for the successful start-up and operation of immigrant-owned businesses in South Africa?

\section{Literature Review}

The literature on small business development in general and immigrant entrepreneurship in particular, is inconsistent as well as inconclusive. Although small business and entrepreneurship in general have been widely researched in both the developed and less-developed countries, this cannot be said of immigrant-owned businesses in the latter. No study in South Africa addresses the business survival strategies that African immigrants utilise.

\subsection{Small business failure rates}

A burning issue that justifies the concern with the establishment and growth of SMMEs is the fact that small businesses tend to have a high failure rate. It has been suggested by Bygrave (1997), and Timmons (1999) as quoted in Swanepoel (2008), that the majority of small business failures occur within the first two to ten years. Evidence from several countries suggests that although immigrants are more likely to start-up a business than natives, their businesses are also more likely to fail. In France for instance, longitudinal data indicates that only $40 \%$ of immigrant-owned businesses (non-EU) created in 2002 were still in existence after five years, compared with $54 \%$ of corresponding native businesses (OECD, 2010). The rates as observed by the OECD (2010) turn to vary according to the economic conditions prevailing in the host country. For instance, when the French economy is doing well, there is a little difference in the survival rates 
between native and immigrant-owned businesses. Generally, the reasons advanced for small business failure can be grouped as exogenous and endogenous.

\subsection{Small business start-up and growth/survival}

According to Von Broembsen, Wood and Herington (2005), the creation of a new business is a two-phase process. The first phase is the start-up phase, a three-month period when (one or more) individuals identify the products or services that the business will trade in, access resources such as finance and put in place the necessary infrastructure which includes staff. When the business is in this phase it is referred to as the start-up phase (Von Broembsen et al, 2005).

The next phase, a period of 3 to 42 months is when this new business begins to trade and compete in the market place. When a business is in this phase of development, it is referred to as a new firm. The definition of a new firm is a business that has paid salaries or wages for longer than 3 months (Von Broembsen et al, 2005). It is therefore, possible to classify a business as a start-up indefinitely if it fails to pay salaries and wages. Once a business has established itself and is more than 42 months old it is referred to as an established business (Von Broembsen et al, 2005).

The TEA index, the primary measure used to compare the rate of entrepreneurship both amongst countries and annual variations with a country, measure the number of new businesses that are started in a given year. South Africa's Total Entrepreneurial activity (TEA) is estimated at 5.15\% (Von Broembsen, 2005). In other words, between $4.32 \%$ and $5,95 \%$ of South African adults between the ages of 18 and 64 have started a business in the last $3 \frac{1}{2}$ years with others or on their own. While a slightly higher figure of 5.4 for South Africa's TEA was recorded in 2004, the difference is not significant and falls within the range of the last 4 years Broembsen (2005). South Africa's ranking has dropped from $20^{\text {th }}$ position out of 34 countries in 2004 to $25^{\text {th }}$ out of 35 countries in 2005.

\subsubsection{Defining and measuring business success}

Acquiring the necessary resources for business start-up and operation has been noted to be a challenging task (Jacobs, 2003). Success draws one's attention to a task satisfactorily completed according to specified standards. In order to measure success, a standard or bench mark must have initially been set, against which the result would be compared (Tengeh, et al, 2011). In business, different dimensions have been used to indicate success. For instance, profit is commonly used to indicate success (Kloosterman \& Rath, 2001). Other indicators of success include survival or numbers of years that the business has existed, which is ultimately indirectly linked to profit, in that a business that does not break even is doomed to close down.

In a study in Germany, Fertala (2006) defined a successful immigrant entrepreneur along the following lines:

- The longer an immigrant survives in business the more successful he or she is.

- The faster the process of incorporating new information than relying on past experience, the more successful the entrepreneur is.

- The greater the sales volume, the more successful the entrepreneur is.

In this article, the duration in business and sales volume are seen as the fundamental indicators of success. In view of the aforegoing, knowing that sales volume and associated cost that signals profit becomes relevant.

\subsubsection{Break- Even Analysis}

A concept used in economics and accounting, break even analysis is the method used to determine the breakeven point in a business venture. The break even point is used to depict that point in a business where no profit has been made, nor have any loses been incurred (Feinberg, 1989). From a managerial or entrepreneurial perspective, the concept of breakeven analysis seeks to find the quantity of output that just covers all costs so that no loss is generated. In this article, we presume an immigrant entrepreneur will not quit the business until such a time when the business is consistently making losses.

The most immportant elements in the break-even analysis are revenues and costs. Whether a business breakseven or not depends on the relationship between the incoming revenues and associeted costs to a significant extent. In terms of the break-even anaysis, a business therefore faces the following strategic options: strick a balance between incoming revenues and associated costs or ensure that such revenues exceed the associated costs. One may suggest that increasing revenue while maintaining or reducing cost becomes a key element in the efforts to ensure business survival or success. As Tozzi (2008) notes, businesses need to rcognise runnaway costs early and make reasonable 
cuts if they have to survive especially during turbulent times.

Tozzi (2008) further notes that some common ways of reducing cost include cutting down on electricity bills, buying cheaper fixtures, using cheaper business space and so forth. As far as increasing revenue is concern the most generic tool utilsed is the 5 Ps (Marketing mix) and immigrant entrepreneurs have been successful in adUopt them to suit their unique circumstances.

\subsection{Immigrant entrepreneurship}

Immigrant entrepreneurship refers to entrepreneurial activities carried by immigrants just after arrival in their host country, either through personal initiatives or with assistance from acquaintances in the host or country of origin. The businesses owned by immigrants are referred to as immigrant-owned businesses. Other terminologies used to describe immigrants who carry out entrepreneurial activities include: ethnic entrepreneur, immigrant entrepreneur and minority entrepreneur.

While noting that in reality the difference between an entrepreneur and a non-entrepreneur does not clearly exist, Fertala (2006) suggests that an immigrant entrepreneur is one who has either:

- Established a business venture or acquired a (family) business alone or with a group of partners, or

- Indicates himself to be self-employed in an incorporated versus unincorporated business.

Considering that there is probably no significant difference between an entrepreneur and a non-entrepreneur as suggested by Fertala (2006), the question that comes to mind would be whether there is a difference between entrepreneurial activities carried out by foreign-born and native entrepreneurs. The answer to the preceding question may lie in the preponderance of business start-up between the two groups as well as the survival rate of these establishments.

\subsection{An overview of the South African immigration regime}

While acknowledging the inconsistent account of the number of immigrants in South Africa noted in the foregoing sections, this section explores the immigration regime in South Africa. Prior to 1998, all immigration to South Africa (including refugees) was centralised and accommodated by the Aliens Control Act 96 of 1991, which was only slightly amended in 1995 by the Aliens Control Amendment Act 76 of 1995 (Minnaar, 2000).

According to Minnaar (2000), the Aliens Control Act 96 of 1991 was an example of a poorly crafted piece of legislation with gross human rights violations. For instance, Minnaar (2000) noted that the1991 Act, among a number of things, provided for:

- Arbitrary stoppages on the streets by immigration officers to identify undocumented immigrants.

- Police to search without a warrant, a suspected illegal immigrant's place of residence once found without a passport or South African identification document.

- Such an arrested 'undocumented' immigrant to be detained immediately at a detention facility or in police cells without being allowed to gather any personal possessions or dispose of property and goods that they might have accumulated in South Africa.

- An arresting officer to sign the removal warrant (Section 44) without the illegal/undocumented migrant ever having a court appearance or access to legal representation once it was established that the arrested suspect was an undocumented immigrant.

- The South African Aliens Control Act made no provision for an appeal through the courts against a removal warrant although other legal arguments for a stay were used to delay or reverse a removal warrant once such was issued.

- In addition, the South African Act made no provision for access to legal counsel or for the provision thereof to a person deemed to be an undocumented migrant, especially after a removal warrant had been issued to such a person.

- In the 1991 Aliens Control Act, there was no provision for immigration tribunals and no specific appeal to the courts on questions of law or a right to legal counsel/representation.

- The Act allowed for the detention of a suspected undocumented migrant for 48 hours, after which a removal warrant had to be issued but the detainee could then be detained for 30 days while awaiting removal/deportation from the country.

- The 1995 Aliens Control Act also set out certain visa conditions with six different categories: tourist, business, work, study, medical (coming in for treatment), and permanent resident. However, if a traveler wanted to 
change the status of a visa while in the country, the Act required them to exit the country and make such application from outside of the country. For instance one could not come into the country on a tourist visa, find a job and then apply for a change of visa status. Furthermore, those seeking to immigrate to South Africa came in under very strict skills-based conditions, only if one had a scarce skill and a job offer, could they come in as an immigrant, or they would need to invest substantial amounts in South Africa (R750 000, approximately US\$100 000).

- There was virtually no provision for the entry of unskilled immigrants. There was also a provision for family reunions, but in 1995 the DHA imposed a condition on South Africans marrying foreigners by making them pay a sum of R7 000 (US\$1 000) in order to try to stop the abuse of the practice of temporary or sham marriages by foreigners trying to get into the country.

- The 1995 Amendment to the Act increased sanctions and fines (up to R40 000 - US\$6 000) on employers employing illegal or undocumented migrants.

- Nowhere in either the 1991 Act or the 1995 Amended Act, is the word 'refugee' or 'asylum seeker' mentioned. Accordingly, such categories of migrants were treated the same as immigrants seeking to come to South Africa and had to apply (from outside of the country) for permits to enter the country.

- No cognisance was taken of their political status in granting temporary residence permits. More often than not they were treated as illegal and undocumented migrants.

In 1996, the Department of Home Affairs initiated a process to re-examine all migration legislation for the purpose of formulating new policies for future migration and the handling of asylum seekers, refugee status and undocumented migrants, which resulted in the so-called Green Paper (a draft policy report of a government department).

\subsubsection{Asylum seekers and refugees}

According to Minnaar (2000), South Africa only began to formally abide by international refugee law after signing the Basic Agreement with the United Nations High Commissioner for Refugees (UNHCR) in 1993. Following that agreement, specific legislation to deal with the granting of refugee status to asylum seekers was only passed in November 1998. The new Refugee Act, Minnaar (2000) believes, was the result of a long period of policy debate and pressure applied by a number of relief organisations. Furthermore, Minnaar (2000) explains that the regularisation of the legal position of refugees in South Africa was largely prompted by the violent scope and extent of xenophobia against foreigners wherein genuine refugees were indiscriminately lumped together with allegedly undocumented migrants, and even those legitimately working on refugee work permits were often attacked and had their hawker stalls destroyed during a number of the anti-foreigner campaigns by locals. In accordance with the Refugee Act, asylum seekers are allowed, once granted refugee status, to become economically active, something natives greatly resent.

Minnaar (2000) further states that for the first time in South African legislation, the Refugee Act sets clear guidelines, in keeping with UNHCR guidelines, for determining the status of asylum seekers and under what conditions they may not be refused entry into the country or be expelled. It also spells out when an applicant will not qualify, and when his or her status can be revoked. The Act also sets a clear procedure for asylum seekers to follow. Maharaj (2009) concludes that the problems facing immigrants and refugees in Durban (a city in South Africa) can be divided into three categories:

- Legal (asylum determination, security of person, documentation)

- Socio-economic/social assistance (health, education, employment and shelter)

- Cultural and economic integration and xenophobia (Tlou, 2004, cited in Maharaj, 2009).

Landau (2010) emphasises the importance of official identity papers for immigrants, and states that although these documents cannot prevent discrimination or ensure social inclusion, they are nonetheless important for finding work, accessing social services, and preventing arbitrary arrest, detention and deportation. According to Landau (2010), two key factors prevent non-nationals from obtaining the documents needed to regularise their stay in South Africa, namely:

- The fact that job seekers cannot apply for employment rights, once in the country. For instance, those coming into the country without an employment offer or study permit cannot claim short term tourist or student visas. Alternatively they can enter through irregular border crossings or apply for asylum.

- The Department of Home Affairs is still one of the most corrupt departments in South Africa despite some improvements in recent years.

Landau (2010) maintains that even those fortunate enough to be granted refugee status still face difficulties in obtaining suitable identity documents. The physical form of the asylum seekers' document itself contributes to delays and 
irregular practices. Asylum seekers, for instance, are issued with a single piece of paper ('section 22' permit) often with hand-written amendments and conditions. Few employers or government agents, including the police and many healthcare workers, recognise these documents as legitimate and moreover the documents become worn out, illegible or even lost because they are carried in the person's pocket (Landau, 2010).

\subsection{South African laws and immigrant-owned businesses}

In keeping with progressive international trends, Maharaj (2009) notes that the new post-apartheid South Africa is a rights-based constitutional democracy. According to Olivier (2002) as quoted in Maharaj (2009), the South African Constitution recognises first, second and third generation rights: civic and political; social and economic; and environmental rights, respectively. As the rights-based discourse gains momentum, Maharaj (2009) argues that groups that have been previously excluded from participating in the social, economic and political life in South Africa (for example migrants) are becoming more assertive and demand inclusion.

Since the advent of democracy in 1994, the South African parliament has passed numerous new bills hoping to positively influence the socio-economic landscape inherited from the previous government. However, Crush and Williams (2001) argue that apartheid-era migration legislation and policy have been slow to come under this new political dispensation. According to Crush and Williams (2001:2), the South African government is yet to come up with an effective policy to address its migration concerns, and in the interim it continues to grapple with how best to deal with what is commonly believed to be a massive increase in clandestine migration and irregular employment.

\subsubsection{Business permits}

The process of obtaining a business permit prior to entry into South Africa is a cumbersome and complex one that is almost unattainable for African immigrants. As of July 2005, anyone applying for a business permit needs to provide certification endorsed by a chartered accountant that the following minimum investment (originating from abroadoverseas) conditions have been met:

- Cash to the value of R 2.5 million

- A capital contribution to the value of R2.5 million; or

- Cash to the value of R 2 million as well as capital contribution to the value of R0.5 million.

The above-mentioned conditions can however be reduced or waived if so requested by the Department of Trade and Industry (DTI), or when the business is within an industry which has been declared to be in the national interest. In addition to the investment criteria mentioned above, an applicant needs to provide a comprehensive plan that clearly notes the short and long term viability of the business. Furthermore, an applicant is to undertake to permanently employ at least five South Africans or permanent residents.

\subsection{Entrepreneurial opportunities, challenges and emerging strategies}

Entrepreneurs are constantly looking for business opportunities and in the course of which they encounter and overcome numerous challenges.

\subsubsection{Entrepreneurial Opportunities}

Kirzner (1973) as cited in Clydesdale (2008) suggested that the existence of opportunity can be linked to either one of the two errors that people make. The first error resulting to failure occurs when people make errors of over-optimism as in the case in the market where one expects to achieve something that cannot be achieved. The second error, namely that of over-pessimism unlike the first provides opportunities. The latter occurs when people believe something cannot be done when in reality it can. In which case, people do not recognise that opportunities exist and are just waiting to be seized. Under this scenario one would imagine what an immigrant who arrives in a new market equipped with different bundles of social and human resources that helps him or her recognise opportunities that others overlooked would do (Clydesdale, 2008).

A reoccurring thread in the literature on ethnic entrepreneurial opportunities emphasizes the fact that immigrants capitalise on niches within ethnic enclaves and only incorporate other markets when the business is well established and have fully adapted to the conditions of the host country. In so doing, they mostly provide products and services for the 
ethnic consumers and often than not most of their goods originate from their countries of origin. However, it is increasing argued in recent studies that immigrant entrepreneurs do not focus on the ethnic market at start-up but rather "fish" beyond their ethnic community. In a related study, Oliveira (2003) noted that Chinese immigrants in Portugal searched for the host society opportunities, combining local, regional, European and transnational connections, drawing on the inner-group's resources. From a resource mobilisation point of view, Elfring and Hulsink (2003) noted the network is an important source of new ideas and lucrative opportunities in that it is a source of information, helping the entrepreneur to locate and evaluate opportunities.

Clydesdale (2008) argues that although immigrant entrepreneurial attributes developed through individual life experiences elsewhere (in another environment) are critical for the start-up and operation of businesses, they (attributes) may sometimes not match with the conditions in the host environment.

\subsubsection{Entrepreneurial Challenges}

In a study of immigrant groups in Britain, France, the United States, Germany and the Netherlands, Roger Waldinger identified seven common challenges that immigrant groups face regarding ethnic entrepreneurship (Waldinger et al, 1990 in Pinkowski, 2009).

These are:

- How they acquire information that they need to establish a business and survive;

- How to acquire capital necessary to fund the business;

- Where to get the training and acquire the skills necessary to run a small business enterprise;

- How to recruit and manage an honest, competent and affordable workforce;

- How to manage customer and supplier relationships especially with different language or business practice models;

- How to survive serious competition in the new environment; and

- How to protect themselves and co-ethnics from political attacks.

Once a challenge such as one of the foregoing has been identified, the immigrant entrepreneur's survival instincts sets in and he or she 'pulls every stunt' to overcome the obstacle.

\subsubsection{The Emerging Strategies}

When faced with challenges, the "survival instinct" inherent in almost all immigrants sets to work. The word "strategy "is derived from the Greek word "strategos" which means generalship and when used in a military sense refers to the art or plan that the general used to overpower the enemy, while taking into consideration his power and the situation at hand (Nutt \& Backoff, 1992).

In a business sense one may logically suggest that a strategy would be a deliberate attempt by an entrepreneur to extend survival as long as possible by staying ahead of its competition while ensuring that the total revenue generated equal or exceeds total cost. Strategies emerge from the interaction of opportunity structures and group characteristics, as ethnic entrepreneurs adapt to the resources available to them, building on the characteristics of their group (Aldrich \& Waldinger, 1990). In an ideal situation, Kloosterman and Rath (2001) note that the focus of these strategies is on matching the supply side and the demand side. On the demand side there has to be opportunities and these opportunities should be accessible.

The composition of immigrant particularly from less developed countries is different from that of the indigenous population in that the newcomers tend to differ in the bundle of resources (human, social, financial and cultural capital) at their disposal when compared with their indigenous counterparts (Kloosterman \& Rath, 2001). Agreeing with Kloosterman and Rath (2001), Guzy, (2006) stated that it is the combination of strong dynamics with strong limiting factors for enterprising migrants that makes immigrants to concentrate in sectors with low entry barriers in terms of qualifications and capital, such as trade, personal services, construction, catering and the clothing industry. According to Levent, Njikamp and Sahin (2007), these immigrants usually set up their businesses where informal production would give them a competitive advantage and where the networks of ethnic people provide them with an informal way of doing business and exchange of information. Guzy (2006) notes that these less competitive sectors are work intensive, and being able to rely on the family and community members is an asset. The enterprise survival rate in these sectors is lower than average, and relying on informal labour can make a difference for the business survival. Also, if the barriers to official self-employment are too high, the activity may not be registered at all (Guzy, 2006). 
From a strategy perspective, the orientation of ethnic enterprises is internal from the beginning in that they start with a focus on clients from their own ethnic groups, with traditional products, services and communication channels (Levent et al, 2007). This internal orientation and mutual trust within the ethnic network provides on the one hand rotating credit, a protected market and a proper labour force while on the other hand it creates a more than average loyalty between the ethnic firm and his clients (Levent et al, 2007). Using a business premise as a dwelling place is a common cost saving strategy used by immigrants at during the start-up face of their business. For instance, Kaknins \& Chung, 2006) notes the case of the Gujaranti (immigrants from the gujaranti state of India) hotel owners in the US.

From a South African context, Maharaji (2009) noted that in the absence of support from the South African government, migrants and refugees in particular depend on support from religious organisation, NGOs and informal networks in times of need.

\section{Methodology}

The article was designed within the quantitative and qualitative research paradigms, in which a triangulation of three methods was utilised to collect and analyze the data. From a quantitative perspective, the survey questionnaire was used. To complement the quantitative approach, personal interviews and focus groups were utilised as the methods within the qualitative approach paradigm. The primary data collection instrument used was the survey questionnaire which was complimented by personal interviews and focus group debates.

\subsection{The Research population}

The research population for this study, comprised of all immigrants of African origin that met the following criteria:

- Respondents muct be from of Cameroon, Ghana, Ethiopia, Senegal and Somalia origin;

- Operate a Small, Medium or Micro Size Enterprise (SMMEs) at the time of interview;

- Business operation must be located within the Cape Town Metropolitan Area; and

- Operation must be three or more years in existence.

\subsection{The Sample Design}

Using the snowballing technique, a sample of 135 immigrant-owned businesses was drawn. According to the snowballing sampling technique, once a suitable respondent is identified, he or she nominates other respondents. McDonald, Mashike and Golden (1999) states that this method allows for an element of randomness and ensures that the confidence of the interviewee would be maintained by being referred by a friend. To avoid the inherent bias associated with snow balling, once a suitable respondent is found, such a respondent assist to identify at least two other ethnic businesses within that suburb, and the researcher randomly selects one for an interview. By tossing a coin, one of the two nominated candidates is selected to be included in the survey. Two approaches were utilised to arrive at the sample size of 135 immigrant-owned businesses. Firstly, a review of the following recent related studies: Basu and Altinay, 2004; Rogerson, 2004; Tesfom, 2006; Kushnirovich and Heilbrunn, 2008; indicted that on average the sample size 118 was determined. The aforementioned studies made utilised the snowballing technique, and the interviews were conducted on a face to face basis. Secondly, in an attempt to justify and to ensure that the same size would provide satisfactory results at a 95\% statistical power, the G*Power software was used. Using G*Power 3.1.2 software, and striving to achieve a statistical power of 95\%, a sample size of 134 was regarded as adequate (Faul, Erdfelder, Buchner, \& Lang, 2009).

\subsection{Data collection and analysis}

The survey questionnaire was utilised as the primary data collection instrument, focus group discussions and personal interviews were conducted to supplement, as well as to test the results of the survey. Two focus group discussions were held in which attempts were made to answer the research questions with particular emphasis on the outcome of the survey questionnaire. The focus group participants were drawn from the same sample from which the survey questionnaire participants were drawn. Two groups of six and seven participants were drawn respectively. In the group session that lasted one and a half hour each, participants shared their experiences as they attempted to provide answers to the research questions. Personal interviews were conducted with key informants, banks and SMME support organisations. The preliminary interviews conducted with key informants was informal and provided information that 
guided the planning and as well as the identification of the sample population. Furthermore, interviews with key informants like focus group discussions also provided a means of validating the survey results. Specifically, a total of four formal interviews were conducted. The choice of whom to interview emerged from a preliminary analysis of the quantitative survey questionnaire and served to corroborate and as well as to complement it. Two interviews were held with officials of the two most prominent banks in South Africa. Another two interviews were held with SMMEs support organisations. These organisations were purposefully chosen with one representing the government and the other representing the civil society.

\section{Results}

An African immigrant entrepreneur was noted to be a male within the age range of 20 and 40 who has been 'pushed' into starting a business by circumstances beyond his/her control. The results that follow were of particular interest to this article.

\subsection{Problems faced by African immigrant entrepreneurs}

Immigrant entrepreneurs face a number of challenges when starting their business and again as they try to grow or stay afloat. These challenges may relate to start up finance and so forth.

\subsubsection{Business start-up obstacles}

Reporting on the obstacles that African owned businesses encountered during the business start-up phase, the results of the quantitative questionnaire show that:

- $77,0 \%$ indicated limited finance as an obstacle;

- $54,8 \%$ reported lack of business space as an obstacle;

- $39,3 \%$ reported lack of appropriate residence permits as a major business start-up obstacle;

- 29,6\% placed emphasis on insufficient demand as a start-up obstacle;

- $21,5 \%$ acknowledged lack of expertise in the concerned business area as an impediment;

- $10,4 \%$ reported lack of information on business-related matters as an apparent business start-up obstacle and;

- $4,4 \%$ reported lack of skilled employees as an obstacle.

Based on the above results, it can be drawn that the three most cumbersome obstacles confronting African immigrant entrepreneurs are finance, business space, and residence permits. Collaborating this finding, Lack of finance, business space and residence permits are some of the themes that were equally emphasised by the participants at the focus group meetings. An interview with officials of two of the most prominent banks in South Africa suggested that lack of finance either for start-up or growth is a problem likely encountered by African immigrants. They further emphasised that due to the difficulties involved with verifying the authenticity of most of the documents used by immigrant, most without a South African identification document (green book) cannot have access to some bank facilities, including owning a bank account. In the past, these immigrants were allowed to open accounts although access to overdrafts and loans was not an option. An interview conducted with two prominent business support agencies indicated that although these organistions offer a wide range of services that include; business advice, market research, skills training, referrals, networking, provision of information, and indirect financial support, most small businesses (immigrant-owned included) seldom make use of these services.

\subsection{Business operational obstacles}

Once started, a business still encounters some obstacles as it grows. From the results of the survey questionnaire, it was noted that:

- Lack of finance was seen as an impediment during this phase of the business by $42,2 \%$ of the respondents.

- As regards business space, a significant proportion $(36,3 \%)$ of the respondents believed that lack of business space was an obstacle to the operation of a business, even after start-up. This finding is consistent with the existing literature on 'blocked opportunities' and in the case of African immigrants in South Africa, this may be related to the non-acceptance of refugee permits by landlords as a form of identification. 
- In terms of skilled employees, the results suggest that 7,4\% of the respondents believed that lack of skilled employees was still a problem even after the start-up phase of the business.

- Only $6,7 \%$ of the respondents reported lack of expertise after the business start-up phase.

- The results indicated that only $0.7 \%$ of the respondents saw the lack of a licence as an obstacle during the operational phase of the business.

- With regard to customers. $20 \%$ of the respondents believed that lack of customers was an obstacle that continued to affect their businesses long after start-up.

- In terms of the flow of information, a significant proportion (40,0\%) of those surveyed believed that lack of information was still an impediment to the operation of their business long after start-up.

- In terms of residence permits, the results indicated that $9,6 \%$ of those surveyed believed that not having the right residence permits was still a problem for their businesses long after start-up.

Based on the results noted above, the three most noted growth obstacles reported are insufficient finance, lack of information, and business space. In addition to the obstacles reported, participants at the focus group meetings unanimously added crime and jealousy to this list.

\subsection{Business Survival strategy}

After starting a business, the entrepreneur strives to grow the business or, at best, maintain the business at a certain level unless closing down becomes a last resort. The focus of this section is to explore those strategies that African immigrant entrepreneurs utilise to ensure the survival of their businesses.

\subsubsection{Cost saving strategies}

With the popularity of any strategy tied to the frequency of usage, African immigrant entrepreneurs noted that they have implemented one or all of the following strategies at one point in the life cycle of their businesses:

- Shared information with others $(91,1 \%)$

- $\quad$ Shared shop space $(81,5 \%)$

- Used informal sources of financing (99.2\%)

- Operated illegally $(79,3 \%)$

- Worked from home, a container or a temporary location $(87,4 \%)$

- Made use of cheap labour $(50,4 \%)$.

From the qualitative point of view, participants at the focus group meetings unanimously confirmed the earlier findings as they indicated that the recession and the disadvantages that they faced in the South African market fortified their adaptive strategies.

\subsubsection{Revenue boasting strategies}

With the popularity of any strategy tied to the frequency of usage, African immigrant entrepreneurs noted that they have implemented one or most of the strategies that follow at one point in the life cycle of their businesses:

- Offering good/services consumed by the wider South African public including people from my country of origin (99.3\%)

- Engaging in bulk buying and bulk breaking activities- that is buying in huge quantities and selling in smaller units $(89,2 \%)$

- Locating near the customers (100\%)

- Offering a variety of goods $(97,8 \%)$

- Even trading in illegal goods $(62,2 \%)$.

- Relocating the businesses as necessary $(89,5 \%)$

At the focus group meetings, participants acknowledged the above-mentioned strategies as being fundamental to the success as well as survival of immigrant-owned businesses in the Cape Town Metropolitan Area of South Africa. 


\section{The Proposed Business Survival Framework}

It has been noted ealier that a business is not an end in itssel and the fact that the ultimate purpose of a business is to provide an income for its owner. For the immigrants of African origin, a majority of whom have been pushed into starting a business, the survival of the business becomes of critical importance.

\subsection{Assumptions underpinning the construction of the proposed framework}

The framework proposed in this study is based on the following assumptions:

- According to Lloyd (2002), a business in general, whether micro, small, or medium, which produces goods and services that are in demand, will have the over-arching aim of generating income for its owners or operators.

- The primary goal of an entrepreneur is to improve or provide an income for him or herself and family. As suggested by the Reserve Bank of Dallas (2010), in a free market, the potential to make a profit provides a huge incentive for entrepreneurs to come up with new and better ideas. Profits are essential signals to entrepreneurs that they are on the right track.

- Profit equals total revenue minus total cost.

- All things being equal, an entrepreneur's business will close down only if total revenue is less than the total cost within the first three years of its existence.

- Business expansion is sponsored using profits or external sources of finance.

Fig 1: Business Survival framework for African immigrant-owned businesses

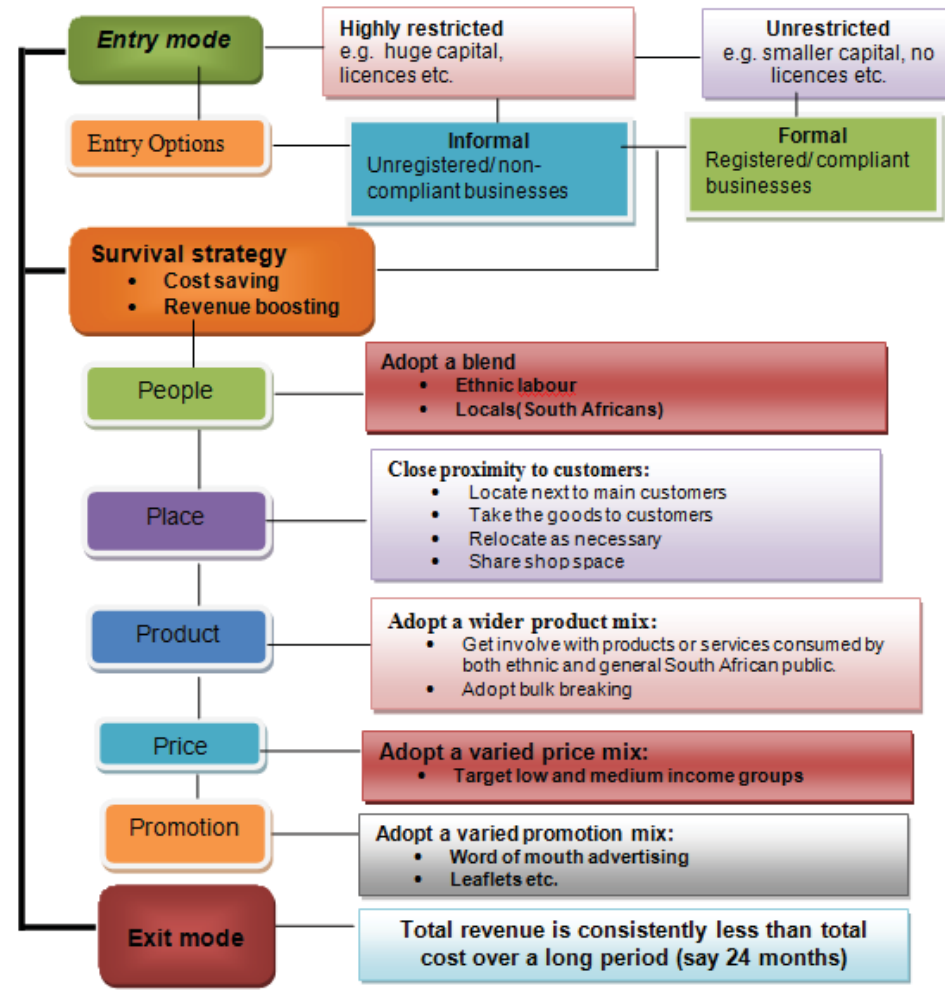

Figure 1: A proposed framework for the survival of African immigrant- owned businesses in the Cape Town Metropolitan Area 


\subsubsection{Business entry mode}

There are basically two ways of getting into business for African immigrants in South Africa. These are the formal entry and the informal entry. On the one hand, the formal mode entails buying a business or starting one from scratch within the formal strata of the economy; on the other hand the same holds true for informal entry except for the fact that it happens in the informal economy. Both modes of entry are somehow linked in that they complement each other. For instance, the survivalist entrepreneur with insufficient resources would find it much easier to start-up a business in the informal sector than in the formal sector. This may be explained by the fact that less resources, especially capital, are required and there are fewer or no regulations to be met. However, as the resource base of the entrepreneur expands, which is noticeable when the business grows and becomes more stable, he or she may want to regularise the business. By regularising the business, the entrepreneur stands a better chance of further expansion as it becomes possible to deal with big businesses, the government, and even the banks.

\subsubsection{Business survival strategy}

For most businesses, once started, the battle for survival is an ongoing one. The need to make a profit as well as to stay in business for as long as possible is one that drives entrepreneurs into devising winning survival strategies. Basic business logic suggests that a business that does not make enough revenue to cover its costs is bound to shut. As part of a business survival tactic, entrepreneurs must ensure that sales revenue exceeds or is equal to cost, and African immigrants seem to have found creative ways of achieving this.

In boasting sales revenue, African immigrants have been noted to fully apply the 'Five Ps' of marketing. For instance, they:

- People: target co-ethnic as employees

- Place: Target the right customers and locate close to their customers.

- Product: offer a variety of goods/services.

- Price: offer low pricing.

- Promotion: Promote their good/services in different ways.

In an attempt to reduce the cost of conducting business, the African immigrants in this study have been noted to adopt the following resource sharing techniques, among other things:

- Capital sharing

- Shop sharing

- Information sharing

- Transport sharing

- Employee sharing.

By employing the revenue boosting and cost saving strategies listed above, the expected life span and success of an African business may be prolonged.

\subsubsection{Exit Mode}

As long as the coming revenues can cover the associated cost of maining the business, the african immigrant like any other entrpreneurs "hangs on". However, if costs exceeds for a persistent duration, it makes sense to close down the business. During such trying times the immigrant entrepreneurs do everything possible to keep the business aflot including:

- Borrowing from co-ethnics

- Taking up a paid work on the sideline to support the business

- Demanding help from other memebers of the family especially those in the diaspora.

When all of the above fails, the immigrant entrpreneur is left with no choice but to close down. In response to why he exited his fomer line of business business, this is what Mohamed said "I was tired of asking for assistance. I just had to let go... but I learnt alot". 


\section{Conclusion}

In this article, we argued that the business survival strategies devised by African immigrants are in response to the challenges that they face while utilizing their inherent entrepreneurial attributes. By drawing a sample of those successful in starting and operating a business, we were able to understand what survival strategies that African immigrants employ in an effort to prolong the survival of their business. We gleamed an in-depth understanding of the problems that African immigrants face as well as the entrepreneurial characteristic(s) that they perceive as contributing the most to the successful start-up and operation of immigrant-owned businesses in South Africa? We therefore conclude by proposing a business survival framework for African immigrants (figure I). We believe that business survival is an ongoing process, and the proposed framework would provide the basis for a proper ongoing self-evaluation for African immigrant-owned businesses in South Africa.

\section{References}

Acs, Z. 2001. The Job Factory. Inc. 23(7) 40-41.

Aldrich, H. \& Waldiner, R. 1990. Ethnicity and Entrepreneurship. Annual Review of Sociology, 16:111-35.

Basu, A. \& Altinay, E. 2002. The interaction between Culture and Entrepreneurship in London's Immigrant Businesses. International Journal of small business, 20(4):371-394.

Bygrave, W. D. 1997. The Portable MBA in Entrepreneurship. $2^{\text {nd }}$ edition. Canada, John Wiley.

Cassia, L. 2006. Entrepreneurship as Regional Development Catalyst. 46 th Congress of the European Regional Science Association, 30 August to 3 September 2006, Volos.

CDE. 2006. Immigrants in South Africa: Perceptions and Reality in Witbank. CDE Focus, Number 9:1-12, May.

Chandra, V., Moorty, L., Nganou, J., Rajaratnam, B. \& Schaefer, K. 2001. Constraints to Growth and Employment in South Africa. Report number 2, World Bank.

Clark, K. \& Drinkwater, S. 2000. Pushed Out or Pulled In? Self-Employment among Ethnic Minorities in England and Wales. http://ideas.repec.org/a/eee/labeco/v7y2000i5p603-628.html. [14 May 2010].

Crush, J. \& Williams, V. 2001. Making up the Numbers: Measuring 'illegal immigration' to South Africa. Migration Policy Brief No. 3 , Southern African Migration Pogramme.

Clydesdale, G. 2008. Business immigrants and the entrepreneurial nexus.Journal of International Entrepreneurship, (6): $123-142$.

Faul, F., Erdfelder, E., Buchner, A. \& Lang, A. G. 2009. Statistical power analyses using G*Power 3.1: Tests for correlation and regression analyses. Behaviour Research Methods, 41: 1149-1160.

Federal Reserve Bank of Dallas. 2010. Everyday Economics. http://www.dallasfed.org/educate/everyday/ev3.html [15 October 2010]

Feinberg, P. 1989. Guide to business survival. Divaris Stein, Johannesburg.

Fertala, N. 2006. Determinants of Successful Immigrant Entrepreneurship in Germany. Unpublished PhD Dissertation. Tubingen University. Germany.

Guzy, M. 2006. Nurturing Immigrant entrepreneurship. A Handbook for Micro Credit and Business Support. Executive summary. European Micro Finance Network. http://www.european-microfinance.org. [25 June 2010].

Jacobs, H. 2003. Resource Requirements and Legal and regulated aspects. In: Nieman, G., Hough, J. \& Nieuwenhuizen, C. (eds.). Entrepreneurship. Pretoria, Van Schaik: 111-128.

Kloosterman, R. \& Rath, J. 2001. Immigrant entrepreneurs in advanced economies: mixed embeddedness further explored. Journal of Ethnic and Migration Studies, 27(2):189-202.

Kushnirovich, N. \& Heilbrunn, S. 2008. Financial Funding of immigrant Businesses. Journal of Developmental Entrepreneurship, 13(2):167-184.

Lee, S.Y., Florida, R. \& Acs, Z. 2004. Creativity and Entrepreneurship: A Regional Analysis of New Firm Formation. Discussion Papers on Entrepreneurship, Growth and Public Policy: 1-23.

Levent, B. T., Njikamp, P. \& Sahin, M. 2007. New orientations in ethnic entrepreneurship: motivation, goals and strategies of new generation ethnic immigrants. Paper presented at the $7^{\text {th }}$ International Conference on Diversity in Organisations, Communities and Nations. Amsterdam, 2-3 July

Markova, S. \& Perkovska-Mircevska, T. 2009. Financing Options for Entrepreneurial Ventures. Economic Interferences. 11(26) 597-604, June.

Masurel, E., Njikamp, P., Tastan, M. \& Vindigi, G. 2002. Motivations and performance conditions for ethnic entrepreneurship. Tinbergen Institute Discussion Paper, 048/3.

McDonald, D., Mashike, L. \& Golden, C. 1999. The Lives and Times of African Migrants and Immigrants in Post Apartheid South Africa. Southern African Migration Project (SAMP). Migration Policy Series, (13)1-33.

Minnaar, A. 2000. Migrant's rights: the South Africa experience post- 1994. Paper presented at the 4th International Conference of the International Society for the Reform of Criminal Law. Sandton International Convention Centre. Johannesburg, December.

Landau, L. B. 2010. Discrimination and Development? Urbanisation and sustainable livelihoods in Johannesburg. In: Crush, J. \& Frayne, B. (eds.). Surviving on the Move: Migration, Poverty and Development in Southern Africa. IDASA, Cape Town: 66-82. 
Maharaj, B. 2009. Migrants and Urban Rights: Politics of xenophobia in South African cities. L'Espace Politique, (8)1-15. http://www.espacepolitique.revees.or/index1402.html. [12 May 2010]

Nieuwenhuizen, C. 2004. Entrepreneurship and Entrepreneurial Skills. In: Nieuwenhuizen, C. (ed). Basics of Entrepreneurship. Cape Town, Juta.

OECD, 2010. Main findings of the conference on entrepreneurship and employment creation of immigrants in OECD countries, 9-10 June, Paris. http://www.oecd.org/dataoecd/11/22/46424942.doc [14 August 2011]

Pinkowski, J. 2009. Challenges and promises for Immigrant Entrepreneurship in Dublin. Dublin City Council Economic Development Unit: 1-63, May.

Rogerson, C.M. 2000. Successful SMEs in South Africa: the case of clothing producers in the Witwatersrand. Development Southern Africa, 17(5):688-716.

Rogerson, C. M. 2004. Pro-poor Local Economic Development in Post-Apartheid South Africa: the Johannesburg Fashion District. Paper presented at the $50^{\text {th }}$ Anniversary Conference: Reviewing the first decade of development and democracy in South Africa. International Convention Centre Durban. 21-22 October.

Sinha, A. 2003. Experience of SMEs in South and South-east Asia. South Asia Enterprise Development Facility: 1-18. December.

Swanepoel, E. 2008. The effect of the interventions of the South African Breweries' kickstart youth entrepreneurship programme on entrepreneurial and small business performance in South Africa. Unpublished PhD dissertation. University of South Africa.

Tengeh, R., Ballard, H. \& Slabbert, A. (2011). A Framework for Acquiring the Resources Vital for the Start-up of a Business in South Africa: an African Immigrant's Perspective. European Journal of Social Sciences, 23(3):362-381.

Tesfom, G. 2006. The role of Social Networks on the Entrepreneurial Drive of First East Africa origin Entrepreneurs in the Seattle Area. Journal of Asia Entrepreneurship and Sustainability. 11 (4). http:// www.asiaentrepreneurshipjournal.com. [10 November 2010].

Tozzi, J. Shifting into cost-cutting mode. Business Week. http://www.sba.gov/sites/default/files/Survival\%20Tips\%20for\%20Managing \%20During\%20an\%20Economic\%20Downturn.pdf [ 01/03/2013]

Van Tubergen, F. 2005. Self-employment of immigrants: a cross-national study of 17 Western societies. Social Forces, 84(2):709-732.

Von Broembsen, M. 2005. A global perspective. In: Von Broembsen, M., Wood, E. \& Herrington M. (eds). General Entrepreneurship Monitor. South African Report: 17-21. Cape Town: UCT Graduate school of business, University of Cape Town.

Von Broembsen, M., Wood, E. \& Herington, M. 2005. General Entrepreneurship Monitor: South African Report 2005. Cape Town: UCT Graduate school of business, University of Cape Town. 